Article

\title{
Amrtasiddhi A Posteriori: An Exploratory Study on the Possible Impact of the Amrtasiddhi on the Subsequent Sanskritic Vajrayāna Tradition
}

\author{
Samuel Grimes \\ Department of Religious Studies, University of Virginia, Charlottesville, VA 22904, USA; smg5ut@virginia.edu \\ Received: 16 January 2020; Accepted: 17 March 2020; Published: 19 March 2020 \\ check for \\ updates

\begin{abstract}
Recent research into source materials for hațayoga (Birch, Mallinson, Szántó) has revealed that the physical techniques and esoteric anatomy traditionally associated with Śaiva practitioners likely found a genesis within Vajrayāna Buddhist communities. The physiology and practices for longevity described in the 11th-or-12th-century Amrtasiddhi are easily traced in the development of subsequent physical yoga, but prior to the discovery of the text's Buddhist origin, analogues to a hațayoga esoteric anatomy found in Vajrayāna sources have been regarded as coincidental. This paper considers both the possibility that the Amrtasiddhi, or a tradition related to it, had a lasting impact on practices detailed in subsequent tantric Buddhist texts and that this hathayoga source text can aid in interpreting unclear passages in these texts.
\end{abstract}

Keywords: Buddhism; tantra; yoga; India; Nepal

\section{Introduction}

This paper will outline an investigation of the possible impact of the hathayoga "source text" upon two late Vajrayāna mūla tantras, namely, the 12th-century Samvarodayatantra (SUT) and the 13th-century Candamahäroṣanatantra (CMT). The hațayoga source text is the 11th-century Amrtasiddhi. This paper will also note some precedents of and parallels with the physiological model found in the Amrtasiddhi in earlier and contemporaneous Vajrayāna texts.

I was first exposed to the Amrtasiddhi in 2016 when James Mallinson regularly came to Oxford to work through it with Péter-Dániel Szántó and I joined in the readings. It was almost immediately evident that the text had Buddhist influences (for example, its opening mangala verse is an invocation to the Buddhist goddess Chinnamastā), and Mallinson subsequently released an article ${ }^{1}$ detailing some of these Buddhist elements. Mallinson and Szántó will publish a full edition of the text and translation in 2020 .

The text first received treatment in contemporary scholarship in Kurtis Schaeffer's pioneering article $^{2}$ in which he pointed out that it is difficult to identify the text as Buddhist, Nātha, or anything else. Schaeffer also highlighted the importance of the text in Tibet. Mallinson especially, ${ }^{3}$ but Jason Birch and others in the last two decades have illustrated the impact of the text upon the development of hathayoga. The goal of this paper is to begin to investigate the impact the Amrtasiddhi may have had on subsequent developments in Sanskritic Buddhism.

For the purposes of this paper there are two key ideas in the Amrtasiddhi I will discuss, which, when combined, would eventually become the fundamental physiological theory of hathayoga. The first

\footnotetext{
A draft of a chapter to be in a forthcoming festschrift for Prof. Alexis Sanderson.

(Schaeffer 2002).

See (Mallinson 2016), (Mallinson 2017), (Mallinson and Singleton 2017), and (Mallinson 2018).
} 
idea is that if one is able to preserve the store of bindu, or amrta, that is, semen, in the cranial vault, that one may extend one's own life. This bindu drips, drop by drop, over a lifetime, and once it is exhausted, the individual dies. In females it is present as well, although as female sexual fluid or menstrual blood, not seminal fluid. The second idea is that through prānāyamma and physical manipulation of the body, a yogin can force wind through the nādīs, the subtle channels of the body, into the central channel and upwards, and reverse the downward course of the ever-dripping bindu for the specific purpose of prolonging one's own life. This is the amrtasiddhi, the accomplishment of immortality.

\section{Precedents in Vajrayāna}

There is a long, well-documented history of alchemy and practices for longevity in Vajrayāna prior to the Amrtasiddhi, ${ }^{4}$ but the text's particular model does not appear to exist in tantric Buddhism, at least not in any of the materials that we are aware known of. That is, the model of a store of life-sustaining substance in the cranium, and the ability to move subtle wind through the channels of the body to propel this substance upwards for the purpose of life-extension or death-prevention. There are, however, similar physiological systems within Vajrayāna prior to the Amrtasiddhi. The examples presented in this section are not intended to be exhaustive (and indeed they are not), but to showcase the existence of such systems in Vajrayāna prior to or within the 11th century.

The concept of something called bindu is found in the 8th-century Guhyasamājatantra as a point upon which a yogin places a seed-syllable visualized in meditation. ${ }^{5}$ There is also a mention of bindu as a drop of seminal fluid produced through sexual union. ${ }^{6}$ In the Guhyasamājottara, the 18th chapter of the Guhyasamajatantra, and likely a late 8th-century addition to the original tantra, we see bindu as an object of the mind during prānāyāma, a drop or point of prāna called "prānabindu". ${ }^{7}$ Here bindu is an object in meditation, the point one places one's own seed mantra upon, not a physical substance; however, it is noteworthy that centuries later, at the time of the Amrtasiddhi's production, the famed Nāropā locates this bindu in the forehead. ${ }^{8}$

The Laghukālacakratantra, or simply Kālacakra, produced circa 1030 CE (so more or less contemporaneous with the Amrtasiddhi), includes four, individual bindus located in respective cakras, which lead to wrong speech and behavior but, when purified, result in a perfected body. This purification happens through binduyoga, where a drop of semen is sent upwards and then diffuses throughout the body, leading to bliss. ${ }^{9}$

As regards the $n \bar{a} \bar{d} \bar{\imath} \mathrm{s}$, a fully developed system of 32 channels, with sun and moon corresponding to the primary right and left channels, respectively, exists in Vajrayāna as early as the late 9th-century

4 For an overview of alchemical practices in both South Asia and Sanskritic Buddhism in general see White, David Gordon. The Alchemical Body: Siddha Traditions in Medieval India. The University of Chicago Press, Chicago and London. 1996. For practices related directly to the Laghukälacakratantra and speculation regarding the wider tradition it draws from, see (Wallace 2001).

5 buddhamandalamadhyastham vajrākṣobhyam prabhāvayet | hūṃkāram hṛdaye dhyātvā cittam bindugatam nyaset || buddhamandalamadhyastham amitābham prabhāvayet | ăhkāram hrdaye dhyātoā vajram bindugatam nyaset || Guhyasamājatantra 11.42-43. "He should visualize Akṣobhya situated in the center of the Buddha mandala; [then] visualizing the HūM syllable in his heart, he should fix [the syllable] at the bindu at the mind. He should visualize Amitābha situated at the center of the Buddha mandala; [then] visualizing the $\bar{A} H$ syllable in his heart, he should fix [the syllable] at the bindu at the vajra."

6 svavajram padmasamyuktam dvayendriyaprayogatah | svaretobindubhir buddhān vajrasattvāmés ca pūjayet || Guhyasamājatantra 7.26. "The two sense organs united, his own penis joined with her vagina, he should worship the Buddhas and Vajrasattvas with drops of his own seed."

7 niścārya pindarūpena nāsikāgre tu kalpayet | pañcavarnam mahāratnam prānāyāmam iti smrtam | svamantram hrdaye dhyātvā prānabindugatam nyaset | Guhyasamājottara 147cd-148. "Exhaling, one should set the great jewel of five colors in the form of a bali (pindarūpena) on the tip of the nose. This is called 'restraint of the breath' (prānāyāma). Having visualized one's own mantra as located in the heart, he should fix [the mantra] on the prānabindu."

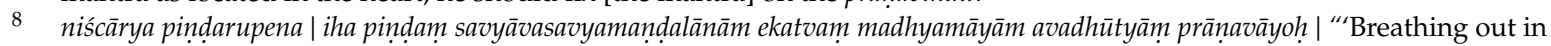
the form of a ball.' Here, the ball is the Prāna wind of the mandalas/areas of the right and left [channels], that is unified in the central channel (madhyamā), the Avadhütī." bindugatam bindusthānam lalātam tatra nyasen nirodhayet | "'at the bindu'. In other words, it must be arrested in the location of the bindu, the forehead." Sekoddeśati $\bar{k} \bar{a}$, commentary on GSU 147c and $148 \mathrm{~d}$, respectively.

9 C.f. (Wallace 2001, p. 22, 200) and the Vimalaprabhā commentary on Kälacakratrantra 4.110. 
Hevajratantra. ${ }^{10}$ With the Kālacakra we see the number of channels suddenly explode to number into the hundreds. The Kălacakra also employs a six-limbed yoga (șadangayoga), detailed in a sort-of commentary on the tantra, the 11th-century Sadangayoga, which comments on a number of texts to explicate its system. Here, in this six-limbed yoga, the goal is upasiddhi, a partial awakening, leading to mahāmudrā, the perfected state ${ }^{11}$ As mentioned before, the deeply complicated subtle body detailed in the Kālacakra mentions bindu, although not quite in the same way as the Amrtasiddhi. The tantra prescribes methods of prānayama, but to put wind into the central channel for the goals of perfection and awakening, not to prolong the yogin's life. ${ }^{12}$ There is an equating of bindu with seminal fluid and a connection with the moon, but this connection is explained by both the Kälacakra and the Sadangayoga as having to do with a co-mingling of fluids in the uterus leading to the development of a fetus, which is part of a larger journey of perfection in which a yogin is influencing his rebirth, or so it seems. ${ }^{13}$

Bindu can be used by the yogin in his own mental transformation towards perfection in the Kälacakra, but what the bindu actually does is not made clear. ${ }^{14}$ Somehow an arresting of the semen at the glans of the penis will bring about awakening if, for whatever reason, a perfected yogin does not reach the ultimate goal at the moment he should - "If he does not get this desired perfection of mantrins through pratyāhāra and so on (that is, through the șadangayoga), he can accomplish it forcefully (hathena) by a repetition of sound by arresting the bindu in the vajra-jewel in the lotus." ${ }^{15}$ Hatha and the involvement of the seminal fluid are a last resort, employed when all else fails.

It is noteworthy that in texts prior to the timing of the Amrtasiddhi, as well as contemporaneous with it, the concept of using force to bring about physical effects is frowned upon in Vajrayāna. Jason Birch and James Mallinson have catalogued over a dozen important Vajrayāna texts that censure using hathayoga. Nearly all these texts are earlier than the 11th-century Amrtasiddhi, although a few are contemporaneous with it; for example, the previously-mentioned Șadangayoga. ${ }^{16}$

So we have a subtle physiology, that is to say a "yogic body", and there is manipulation of vāyus around the body, and, in the case of the Kälacakra and its subsequent tradition, a stoppage of the flow of seminal amrta/bindu through the body. But even with all this, we do not have the models of life-extending $b i n d u$, or techniques to send the substance back up into the cranial vault. That is, we have models where bindu functions as a means to an end, but there are no models where bindu is the end itself, so to speak. However, variations of this model exist in Vajrayāna after the Amrtasiddhi, in both

10 ta eva lalanārasane candrasūryau prajñopāyau—corresponding Yogaratnamālā comm. To Hevajratantra I.i.21. "So the moon corresponds with lalan̄ (the left channel) and wisdom and the sun corresponds with rasana (the right channel) and means."

11 pratyāhārādibhih syāt kuliśakamalajenāmrtenopasiddhih | Kälacakratantra 4.113.i.cd "Near realization (upasiddhi) [is possible] through pratyahära and so on, as well as through the amrta that arises from the Vajra (kuliśa) lotus." The gloss of kuliśakamalajenāmrtena in the Șadañgayoga makes clear the identity of amrta as seminal fluid. tathā dhyānam prānāyāmaś ca dhāraṇa ca | kuliśakamalajenāmrtenācyutenopasādhanam nītārthena| "Thus, [near-realization also concerns] contemplation, restraint of the breath and retention (of semen). "The near-realization", according to the deep meaning, is carried out "by means of the ambrosia", viz., the non-emitted [bodhicitta] (acyuta) "that rises from the adamantine lotus"." Translated in (Sferra 2000, p. 256).

12 prānāyāmena śuddhah śaśiravirahitah pūjyate bodhisattvaih | mārakleśādināśam viśati daśabalam dhāranayā balena | Kālacakratantra 4.118.ii "Purified through restraint of the breath, and thus devoid of the moon and sun, he is honored by the Bodhisattvas. By dint of retention, he comes into conjunction with the ten forces, corresponding to the destructions of the four Māras, of the afflictions, etc." Translated in (Sferra 2000, p. 264). Corresponding Sadaingayoga commentary-prānāyāmena śuddha iti ha yadā raviśaśimārgarahito yoḡ̄ bhavati sadā madhyamāvāhas tadā prānà̃yàmena śuddhah san pūjyate bodhisattvaih praśasyata ity arthah | mārakleśádināśam viśati daśabalam iti śūnyatābimbam grāhyagrähakacittam viśati |d dhāraṇāya baleneti prānaysả gatägatakșayenaikalolïbhavati| "This means here, when the yogin becomes devoid of the sun and moon ways and his [breath] always flows in the central channel, then, being "purified through restraint of the breath, he is honored," viz. praise, "praised by the Bodhisattvas. He comes into conjunction when the ten forces, corresponding to the destruction of the Māras, of the affliction, etc." In other words, the mind, as both perceivable and perceiver, enters into the image of voidness. "By dint of retention," viz., by force of eliminating the coming and going of the breath, he reaches a state of complete unification (ekalolībhavati)." Translated in (Sferra 2000, p. 269).

13 For a description of this process, see (Wallace 2004, pp. 57-64).

14 (Sferra 2000, p. 261).

15 nādābhyāsād dhathenābjagakuliśamanau sādhayed bindurodhāt | Kālacakratantra 4.119.ii.cd. Birch discusses this passage and its treatment in subsequent commentarial literature on (Birch 2011, p. 535) article on uses of the term "hatha".

16 The word hatha does not appear in either the Samvarodayatantra or Candamahāroṣanatantra-we see balena rather than hathena, and we see balena regularly in the context of forcing vāyu through the channels. 
the SUT and the CMT. That is to say, this model of an ever-dripping, life-extending seminal bindu that can lengthen life and empower the yogin if he manages to get it back into his cranium, through some means.

Yet, there is no smoking gun, an "ity amrtasiddhih" or obvious direct quotation. But I believe the accumulation of the uncanny connections is enough to make the case that, even if the texts were not drawing directly from the Amrtasiddhi itself, they were likely drawing from the same socio-religious paradigm from which the Amrtasiddhi was produced. Francesco Sferra tells us that the Sadangayoga is actually a "collage of quotations"17 drawn from a number of works, giving us the impression that this text, and by extension possibly the Amrtasiddhi (as well as the Kälacakra), are products of a larger movement within late, esoteric, Sanskritic Buddhism. ${ }^{18}$

\section{The Samvarodaya and Caṇụamahāroṣaṇa Tantras}

Circumstantial evidence links the Samvarodaya and Candamahäroṣana tantras to the overall movement towards physical yoga in Vajrayāna, as reflected in the Kālacakra tradition, but none of it ties either tantra specifically to the Amrtasiddhi.

\subsection{Subtle Physiology Similarities with Amrtasiddhi}

In both the SUT and CMT, we see discussions detailing moving vāyu around the body, with the fifth chapter of the SUT and the 22nd chapter of the CMT devoted to the subject, but as mentioned before, prānayañma is integral to Kālacakra literature as well. There is also an association in the SUT and CMT of the sun and moon with various $n \bar{a} d \bar{\imath} \mathrm{s}^{19}{ }^{19}$ but this idea is also found in Kālacakra literature, as is the concept of these internal celestial bodies eclipsing one another.

But there are similarities in the two tantras that do not seem to be found anywhere in Vajrayāna prior to the period of the Amrtasiddhi's creation. We find a development of a kundalini analog in the Amrtasiddhi's 13th chapter. Here the wind itself ascends the body of the yogin through the female central channel (madhyam $\bar{a}$ ) and pierces (vedha) its way to the top through a series of knots (granthi), culminating in breaking through the door of Brahmā (brahmādvāram). This makes yoga successful (yogah prasidhyati), along with the completion of the Great Seal (mahāmudrā) and the Great Lock (mahābandha) ${ }^{20}$ In the SUT's 31st chapter there is a similar scenario, where a dormant female energy that lies at a knot around the base of the spine, is moved to action and ultimately ascends the body of the yogin. However, this female energy in the SUT is identified as "yogini", ${ }^{21}$ which is neither the name given in the Amrtasiddhi for the central channel itself, which is madhyam $\bar{a}$, nor the kundalinī of hațhayoga.

17 "Anupamarakșita, who is quoted by Nāropā (956-1040), lived between the end of the X and the beginning of the XI century. His main work, the ȘY, cannot be considered original. Apart from the nine initial stanzas composed by the author, this text consists of a well arranged collage of quotations drawn from other works and connected sporadically through short sentences. Furthermore, the central corpus of these quotations is also present in a later work, the SUṬ by Nāropā, who quotes one of the introductory verses by Anupamarakșita." (Sferra 2000, p. 43). For Sferra's treatment of this milieu see (Sferra 2005).

18 This particular physiological model, that is, of the manipulation of winds through channels in the body into the central channel and then upwards to propel bindu to the cranium (and sometimes beyond) has been related to me by a number of Newar Vajrācārya and Buddhācārya (a subdivision of Śākyas who are caretakers of the Svayambhū Mahācaitya) informants as the means by which a person both stays alive and potentially extends one's own life. Newar Buddhism is, of course, the only remaining Sanskritic Buddhism.

19 The equating of the sun and moon with semen and menstrual blood respectively also pervades the Candamahärosanatantra, since the co-mingling of the two leads to the production of a fetus in a way paralleling that in the Kälacakratantra. The mixture of these two fluids (or vaginal fluid rather than menses) is the standard biological explanation for the generation of a fetus in premodern Sanskrit texts.

20 See Amrtasiddhi 13.5-12.

21 This yogin̄i is of four types according the the SUT_padminī, hastinī, śankhinī, or citrin̄i. These names are found in a number of lists ranging from Vajrayāna yoginīs (four female members of the jñānacakra in the 12th-or-13th-century Ḍakkarnavatantra chapter 15), to kinds of women in kämaśāstra (the first chapter of the Anangaraniga is devoted to detailing these four types of women). A few hathayoga texts include members of this list as names of channels (śankhini appears in the list of the 14 channels in the 13th-century Vasisthasamhitā 2.21-23, the 14th-century Śivasamhitā 2.14-15 and the 17th century Hatharatnāvalī 4.34-35. Śaivasaṃhitā 2.18 also names citrā as a channel. 
A unique similarity with the Amrtasiddhi is found in the 22nd chapter of the CMT, the vāyuyogapatala. Here we see a placement of the five winds that mirrors the Amrtasiddhi, with prāna at the heart, apanna in the anus, samāna around the navel, udāna around the throat, and vyāna pervading the body. ${ }^{22}$ The only other place we see this particular organization of the five vāyus predating the Amrtasiddhi is in the 6th-century Śaiva Niśvāsatattvasam hitā Nayasūtra; ${ }^{23}$ however, it is possible that such an organization has been overlooked elsewhere. The CMT could have taken this organization from the earliest mantramārga text, although it seems that a tradition within Vajrayāna, one which the Amrtasiddhi may be connected to, is a more probable source. The Padmāvatī commentary of the CMT links a breathing yoga to obtainment of five abhijñas, or superknowledges of a Buddha, but there is nothing regarding life-extension.

\subsection{Storage of Bindu in the Cranial Vault}

We also find mention in both the SUT and CMT of a store of amrta ${ }^{24}$ above the ghantikarandhra, that is, the hole just behind and above the uvula. The model in the SUT is clear. "In the Sambhogacakra [which is situated] in the throat, there is a red lotus of sixteen petals; in the middle of the lotus is the character OM; above the character, amrta flows incessantly through the way of the "hole in the uvula", 25 that is, the ghantikārandhra. This model, of an endless flow of amrta is certainly prevalent later on in hathayoga, such as in the khecarimudrā where the yogin bends his tongue back to catch the dripping liquid. ${ }^{26}$

The CMT presents this model of a store of amrta in the cranium above the ghantikatrandhra in a peculiar way. Following coitus, the yogin is told he "should inhale [his ejaculate] through a pipe in his nose to increase his power." ${ }^{27}$ The Padmāvati commentary of the CMT tells us "sometimes he should draw [male and female sexual fluids] from the Lotus (i.e., a female sexual organ) with his mouth, place them in a vessel, insert a straw (nālikām), take note of his breath, and ingest it through his nostril, that is to say the aperture [beyond] the uvula"; the ghanțikärandhra. ${ }^{28}$ After giving an alternate way

22 hṛdi prāno vasen nityamapāno gudamandale | samāno nābhideśe tu samodānaśca kanthake || vyāno vyāpi śarīre ca pradhānāh pañca vāyavah $\mid$ Amrtasiddhi 6.7-6.8ab. "Präna always resides in the heart, apāna in the anus, samāna in the region of the navel,

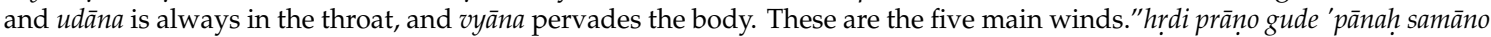
nābhideśake | udānah kanțhadeśe tu vyānah sarvaśarīragah || Candamahāroṣanatantra 22.1 "Prāna is in the heart, apāna is in the anus, samāna is in the region of the navel, udāna is in the area of the throat, and vyāna is in the all the body."

23 hrdgude nābhikaṇthau ca sarvasandhau tathaiva ca| prānāadyās saṃsthitā hyete rūpam śabdañ ca me śṛ̣u \|| Niśvāsatattvasamhitā Nayasūtra 4.119. "Beginning with prāna, these are situated [with prāna] in the heart, [apāna] in the anus, [samāna] in the navel, [udāna] in the throat, and [vyāna] in every joint." The Niśvāsatattvasaṃitā shared several similarities with early Vajrayāna (C.f. Goodall 2015, pp. 31-32). In fact, the verse just preceding Nayasutra 4.119 prescribes the use of dhärañis along with pratyāhāra and prānāyāma, among other techniques. The issue at stake here is the particular arrangement of the winds, that is, which corporeal location each corresponds to. The five (prāna, apāna, udāna, samāna, and vyāna) also find the pattern of corresponding to the wind names Nāga, Kurma, Kṛkara, Devadatta, and Dhanañjaya before the Amrtasiddhi (for example, the pre-10th-century Śaiva Svacchandatantra 7.17) and after the Amrtasiddhi (for example, the 18th-century hathayogic Gherandasamhitā 5.61). The Gherandasamhitā also has the arrangement of the five winds found in the Amrtasiddhi (GhS 5.62), but this is a direct quotation of the Amrtasiddhi, and within a tradition locating authority in the older text. For more arrangements of the five winds (although not the model found in the Niśvāsatattvasamhita, Amrtasiddhi, and Candamahäroṣanatantra detailed above) see Zysk, Kenneth G. "The Bodily Winds in Ancient India Revisited." In The Journal of the Royal Anthropological Institute, vol. 13, pp. S105-15. 2007. For a further description of the record of the five winds in the Niśvāsatattvasaṃitā and yoga texts in general see (Mallinson and Singleton 2017, pp. 187-98).

24 Mallinson notes a handful of Śaiva texts with the model of a store of amrta in the cranial vault in (Mallinson 2007, p. 28, $\mathrm{n}$. 123). These texts are Siddhayogeśvarīmata pațala 11, Mālinīvijayottaratantra 16.53-54, Kaulajūānanirnaya 5.5-13, and Netratantra pațala 7. All these texts predate the Amrtasiddhi.

25 kaṇthe sambhogacakre șodaśadalam raktạ̣ tanmadhye omkāram | tasyordhve ghanțikārandhramārgenāmrtam sravati nirantaram \| Samviarodayatantra 31.24, Translated in (Tsuda 1974, p. 326).

26 For a detailed description of this practice see (Mallinson 2007).

27 nāsayā nalikāyogāt pibet sāmarthyavrddhaye | Caṇdamahāroṣanatantra $6.75 \mathrm{ab}$

28 kadācit padmān mukhenākrștam bhājane samsthāpya nālikām prakṣipya śvāsam jūātvā nāsikayābhyavaharet | ghanțikārandhreṇety

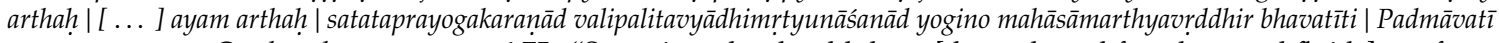
commentary on Candamahärosanatantra 6.75. "Sometimes he should draw [the male and female sexual fluids] out from the Lotus with his mouth, place them in a vessel, insert a straw, take note of his breath, and ingest it through his nostril, that is to the aperture [beyond] the uvula (ghantikärandhra). [ . . ] The meaning is this: by constantly performing [these] procedure[s], there will be a great increase in the yog ${ }^{\prime}$ 's strength, inasmuch as he will stop wrinkling, greying, and [even] death." Translation (Grimes and Szántó 2018, p. 686). The practice may be intellectually connected to the idea of circulation 
to nasally ingest these substances, the commentary tells us why one should do this-“"by constantly performing these procedures, there will be a great increase in the yog $\bar{\imath}^{\prime} \mathrm{s}$ strength, inasmuch as he will stop wrinkling, greying, and [even] death." ${ }^{29}$ When considering the model we find in the Amrtasiddhi, this procedure suddenly seems less strange. Bearing in mind the model of a store of life-extending amrta above the aperture behind the uvula, I suggest the technique the CMT prescribes is alchemical, performed, as it says, to stop aging and even death. The Kälacakratantra itself details a number of elixirs to eliminate wrinkles and gray hair; however, there is no mention anywhere of sending seminal fluid into the cranial vault by nasal means for the purpose of death-prevention.

\subsection{Amrtasiddhi as a Textual Interpretation Aid}

It looks as if the Amrtasiddhi may potentially help clear up textual puzzles in subsequent Vajrayāna works. In the SUT, the description of bindu ascending the body through a progression of corporeal locations corresponding to vowel characters reaches its climax by saying that on the day of the full moon, the yogin $\bar{\imath}$ (the apparent kundalini analog who/which has presumably been travelling upwards with the bindu) is to the left and the right of mada (intoxication, intoxicating, or even semen, among other meanings). ${ }^{30}$ Now this makes no sense. What is mada doing here? The Tibetan translator changed the meaning to mürdhan (forehead or head), ${ }^{31}$ which thematically makes sense, since the bindu is in the cranium at this point, but the Sanskrit manuscript witnesses all read mada. The SUT has a chapter on mada, devoted to spirituous liquors and their production, so there is precedent with the term in the text, but not in a way that makes sense here. We can of course guess that the meaning of mada is essence or seminal fluid, but the text does not give us precedence to do so.

The seventh chapter of Amrtasiddhi can strengthen the case of this interpretation, however. It glosses bindu by equating it with several apparent synonyms. "This is bindu, this is candra, this is bija, this is mada, this is tattva, this is jīva, this is the essence of everything." ${ }^{\prime \prime 2}$ So here we have mada used in the SUT as the thing in the midst of the ascended yogini at the aperture of the head following a

of vital winds in the practice of prānāyāma through the nostrils into and out of the body, in addition to replenishing vital energies stored in the cranial vault. However, such a theory is entirely speculative.

29 A similar practice involving a straw sending a mixture of seminal fluid and menses into a person's naval cavity is found in Vagiśvarakīrti's 11th-century Mṛtyuvañcanopadeśa (Teaching on the Cheating of Death), although in a different context than the one found in the CMT. Whereas the purpose of the practice detailed in the CMT is for a living yogin, the procedure detailed in the Mṛtyuvañcanopadeśa is intended to revive a recently-deceased corpse. mrtasamjīvanam api kva cid drsțam

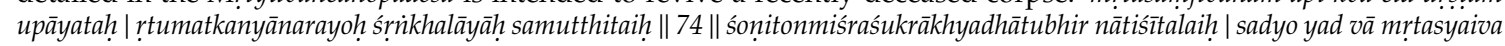
patitair dhātubindubhih || 75 || ghṛtāktanalikārandhranirgamena praveśitaih | vahed ātmīyanāsāgrapuțonnītapute kramāt || 76 ||

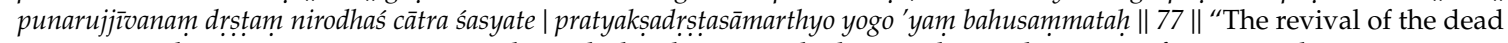
is even seen by an appropriate means, through the elements which arise due to the union of a man and a menstruating young woman. Namely this occurs with the ingredients being semen mixed with uterine blood, which is not too cold (i.e., fresh), or with drops of those same substances (or "of that same substance") which have fallen from the dead body itself. By [those drops] entering the space through a straw smeared in ghee (presumably as a lubricant to get up to the nasal cavity) he should send it in stages into the nostril [of the dead], [having already] drawn it up into the cavity of his own nose. The revival is seen, and the restraint is here detailed. The effectiveness of this practice, respected by many, is clearly observed." Mrtyuvañcanopadeśa 3.74-77. I translated nirodha as restraint, because it perhaps refers to the necromancing yogin holding the substances up his own nose, before deploying them into the nose of the deceased. Two translations have been done of this work, one in English and another in German. The English, translated by Michael Walter under the title "Cheating Death," is not reliable (although it is useful as a summary and outline of the text), and it appears in Tantra In Practice (ed. David Gordon White 2000). Although he does not specify if he translated from the Sanskrit or the 11th-century Tibetan translation, Walter's inclusion of untranslated Tibetan words suggests he translated from the latter. Johannes Schneider's 2010 study, edition of the Sanskrit text, and German translation is recommended for further study. For biographical details on the text's monastic author, Vagīśvarakīrti, see Tāranātha's Rgya gar chos 'byung. For the geographic range of Vagīśvarkīrti's intellectual influence, see Péter-Dániel Szántó's chapter in a forthcoming festschrift for Prof. Alexis Sanderson; and for Vāgīśvarakīrti's impact in Nepal see Iain Sinclair's 2016 dissertation "The appearance of tantric monasticism in Nepal: A history of the public image and fasting ritual of Newar Buddhism, 980-1380" pp. 57-61. I thank Shaman Hatley for drawing my attention to the Mṛtyuvañcanopadeśa.

30 madasya vāmadakșine pürnamāsyām amahsvabhāvā| Samvarodayatantra 31.34 "On the day of the full moon, there is [the goddess] who has the nature of the characters $\dot{A} M$ and $A H$ left and right of mada." Translated in (Tsuda 1974, p. 328).

31 spyi gtsug in the Tibetan.

32 idam bindur idam candram idam bījam idam madạ | idam tattvam idạ̣ jīvah sarvasāramayam tv idam \|| Amṛtasiddhi 7.3 . Unpublished edition Mallinson \& Szántó. 
description of bindu's ascent, and we have the Amrtasiddhi telling us that mada can mean bindu. I do not think it is a stretch to interpret the SUT's mystery mada as bindu. In fact, mada is also mentioned at the beginning of this overall section in the SUT when we are told that a subtle, four-petalled lotus is located in the mahassukhacakra in the head and that it is the place of mada. Again, the place of intoxication makes no sense in this context. We can see that mada must refer to bindu, and the Amrtasiddhi gives us support. Just below this, mahāsukhacakra is said to be a 32-petalled lotus from which the syllable HAM flows downwards-“hamkinaro'adhomukham sravati." ${ }^{33}$ We are told that this 32-petalled lotus is bijabhüta, made of seed. Here, again, the Amrtasiddhi can potentially clear things up if we take take bijabhüta to mean this 32-petalled lotus is made of bindu; however, it is also possible bijja refers to the downward-flowing $H A M$, since $b \bar{i} j a$, or more frequently svabijja, has the esoteric sense of referring to a seed syllable.

\section{Final Remarks}

Based strictly on the materials reviewed here, namely the Samvarodaya and Candamahāroșana tantras, it does not appear that the Amrtasiddhi was important in subsequent Sanskritic ${ }^{34}$ Vajrayāna textual traditions. While the physiology the yogic text employs does include innovations which seem to be found in these two tantras, the lack of any quotations or references to the text itself makes the possibility of drawing a direct connection very unlikely.

Techniques for placing bindu back into the cranium, whether through the circulation of wind detailed in the Amrtasiddhi, or snorting it through a straw as in the Candamahärosanatantra illustrate common physiological models, but not a textual connection. The shared organization of the five winds in this tantra and in the Amrtasiddhi is striking, ${ }^{35}$ but again, this may be attributed to something wider than a single-possibly originally fringe-yogic text. The ability of the Amrtasiddhi to clarify the otherwise-confusing usage of mada in the Samvarodayatantra also lends support for the existence of a shared intellectual landscape regarding subtle physiologies and how the body might be manipulated

33 śirasi mahāsukhacakre caturdalapadmam sukșmam | madasthānam sarvasyādhārarūpatvāt || 19 || bodhimandasvabhāvam bījabhūtam bāhye dvātrimśáaddalapadmam | tanmadhye hamkāro'dhomukham sravati || 20 || Samvarodayatantra 31.19-20 “A subtle, four-petalled lotus is [located] in the mahāsukhacakra in the head. It is the place of mada due to its being the supportive form of everything. Outside [of it] is a thirty-two petalled lotus made up of bijja [and] having the nature of the seat of awakening. In the middle of it is a HAM syllable that flows downwards." Translated in (Tsuda 1974, p. 328). Alexis Sanderson pointed out to me that "adhomukham" could mean "facing downwards" here, in the sense that the imagined character of the seed syllable is turned upside down, but added either reading is possible, and an obvious one is not clear. (Personal communication on 29 September 2019) The reading of an upside-down seed syllable is supported a few lines later in the 25th verse of the same chapter-hṛdaye dharmacakram aṣtadalam viśvapadmam madhye hümkāram adhomukhasthitam | "An eight-pedalled viśva lotus (lotus with pedals facing both up and down, recognizable from Buddhist iconography as the throne sat upon by Buddhas) is in the heart. In the middle [of the lotus] is situated a HŪM syllable facing downwards." The flowing from HAM could still be downwards, regardless of which direction the seed syllable is facing, so the ambiguity remains.

34 Since they are recorded entirely in Tibetan, and not translations from Sanskrit or any Sanskritic tradition, I have not included mention of the biographies of Sāriputra (1335-1426 CE), the East Indian abbot of Mahābodhi temple in Bodh Gayā during a period typically viewed as being after Buddhism had disappeared from within the borders of modern India. His life is detailed in-depth in Arthur McKeown's 2019 Guardian of a Dying Flame, Harvard Oriental Series 89. At a point within Śāiputra's exoteric biography, recorded in the margins of the manuscript McKeown examined, are details of practices similar to those in the Amrtasiddhi intended to extend life, taught to the abbot by his teacher Gholenāth (whom he wrote a biography of). Coincidentally, it is today the position of the Nāth sampradāya that hathayoga originated with their order. By extension, due to its being a foundational text for hathayoga, there would be teachings of the Nāths originating in the Amrtasiddhi, meaning that if Śāriputra had a Nāth guru, it is possible he received teachings from, or at the very least, connected with a tradition placing authority on the Amṛtasiddhi. Śāriputra also reportedly authored a biography of Gorakhnāth (Gorakșa), one of the nine Nāths of the Nāth sampradāya who is credited with founding the order. There is another possible connection between Śāriputra and the Amrtasiddhi一the Mahābodhi temple abbot also penned a biography of Virūpakșa, the mahāsiddha praised in the opening of the Amrtasiddhi. In this biography Śāriputra details a sādhana taught to Virūpakṣa by Chinnamastā herself, the Buddhist goddess praised in the Amrtasiddhi's opening mangala verse. For more on Śāriputra's life see the translations and editions of the various biographies and autobiographies recorded in Tibetan and attributed to him in the appendices of McKeown's 2019 book, and McKeown's explanations of what is recorded in the primary sources in the corresponding chapters. For a detailed examination of the possible Buddhist connections of the early Nāth sampradāya see Mallinson, James. "Kālavañcana in the Konkan: How a Vajrayāna Hațhayoga Tradition Cheated Buddhism's Death in India." Religions, 10, 273.: 1-33. 2019.

35 Since its only chronologically antecedent location is an early Śaiva text! 
for longevity. As mentioned in the opening, Mallinson has made clear the importance of the Amrtasiddhi on subsequent hathayoga traditions. The present inquiry could be expanded to ask, not only why the text did not gain traction within Sanskritic Vajrayāna traditions, but also why it was nevertheless so successful in the so-called "Hindu" hathayoga ones.

Far more study needs to be done on the milieu from which all these ideas were generated. For example, the Samvarodayatantra has a chapter on "rasāyana" that is as yet unedited. There is a project underway by a group of Japanese scholars to slowly edit the Padmini commentary of the Samvarodayatantra and I am myself in the process of editing and translating the Padmāvati commentary of the Candamahäroṣanatantra. The Dākarnavatantra, which is contemporaneous with the Samvarodaya and Candamahāroșana tantras, apparently has lengthy discussions of physical manipulation of the subtle body, however, with the exception of its apabhramśa songs, it remains unedited. David Grey and others are in the process of editing and translating the Sanskrit text. There is also a need for a comprehensive collation of materials preserved in Tibetan, Javanese, Khmer, and other translations, as the Buddhist yogic tradition was never confined to India and it continues to this day.

Funding: This research received no external funding.

Acknowledgments: Thank you to Glen Hayes for organizing the 2019 Society for Tantric Studies Conference in Flagstaff, Arizona, and thank you to Paul Donnelly for hosting it at Northern Arizona University. Thank you to James Mallinson for sharing some of his unpublished work with me, and thank you to Péter-Dániel Szánto for sharing an unpublished version of the Amrtasiddhi edition. Thank you as well to the anonymous reviewers who took the time to read and comment on this work. Your comments were very helpful and significantly improved this work.

Conflicts of Interest: The author declares no conflict of interest.

\section{References}

\section{Primary Sources}

Amrtasiddhi. Unpublished draft edition by James Mallinson and Péter-Dániel Szántó.

Candamahāroṣanatantra. 1974. Unpublished draft edition by Wieisiek Mical. Edition and translation of chapter 1-8 by Christopher George. New Haven: American Oriental Society.

Guhyasamājatantra. Yukei Matsunaga, ed. 1978. Osaka: Toho Shuppan.

Hevajratantra. 1959. Edition, translation and critical study by David Snellgrove. London: Oxford University Press. Kālacakratantra. Biswanath Banerjee, ed. 1985. Kolkata: The Asiatic Society.

Mṛtyuvañcanopadeśa. Johannes Schneider, ed. 2010. Vienna: Verlag der Österreichischen Akademie der Wissenschaften.

Padmāvatī of Mahāsukhavajra. Nepal National Archives. NAK 3-402. NGMPP B 31/7. Apographs consulted-Kyoto University Library no. 38, Univ. of Virginia IAWSR MBB-I-76, Baroda Oriental Institute no. 13274.

Șadangayoga of Anupamarakṣita. Edition and annotated translation. Roma: Instituto Italiano Per l'Africa E l'Oriente.

Samvarodayatantra. Shinichi Tsuda, ed. 1974.Tokyo: Hokuseido Press. Mss consulted-Tokyo Matsunami's Catalogue no. 404, Hodgson RAS no. 38.

Sekoddeśațīkā of Nāropā (Paramārthasamgraha). 2006. Critical Edition of the Sanskrit Text by Francesco Sferra. Critical Edition of the Tibetan Translation by Stefania Merzagora. Roma: Instituto Italiano Per l'Africa E l'Oriente.

\section{Secondary Sources}

Birch, Jason. 2011. The Meaning of hatha in Early Haṭayoga. Journal of the American Oriental Society 131: 527-54. Goodall, Dominic, ed. 2015. Niśvāsatattvasaṃhitā. In collaboration with Alexis Sanderson \& Harunaga Isaacson. Early Tantra Series 1; Pondicherry: Institut Français de Pondichéry, Hamburg: Universität Hamburg, Paris: École française d'Éxtrême-Orient.

Grimes, Samuel, and Péter-Dániel Szántó. 2018. Mahāsukhavajra's Padmāvatī Commentary on the Sixth Chapter of the Caṇ̣amahāroṣaṇatantra: The Sexual Practices of a Tantric Buddhist Yogī and His Consort. Journal of Indian Philosophy 46: 649-93. [CrossRef] 
Mallinson, James. 2007. The Khecarīvidyā of Ādinātha: A Critical Edition and Annotated Translation of an Early Text of Hathayoga. London and New York: Routledge.

Mallinson, James. 2016. The Amṛtasiddhi: Hathayoga's tantric Buddhist source text. In Festschrift for Professor Alexis Sanderson. Forthcoming.

Mallinson, James. 2017. Textual and Material Evidence for Links between Buddhist and Śaiva Tantric Yogins in Western India in the 11th-15th Centuries CE. Handout for Talk at Harvard University.

Mallinson, James. 2018. Early Hathayoga, Unpublished.

Mallinson, James, and Mark Singleton. 2017. Roots of Yoga. New York: Penguin Classics.

Schaeffer, Kurtis. 2002. The Attainment of Immortality: From Nāthas in India to Buddhists in Tibet. Journal of Indian Philosophy 30: 515-33.

Sferra, Francesco. 2005. Constructing the Wheel of Time: Strategies for Establishing a Tradition. In Boundaries, Dynamics, and Construction of Tradition in South Asia. Edited by Federico Squarcini. Florence: Firenze University Press, pp. 254-85.

Tsuda, Shinichi. 1974. Samvarodayatantra. Selected Chapters. Edition and translation. Tokyo: Hokuseido Press, Mss consulted-Tokyo Matsunami's Catalogue no. 404, Hodgson RAS no. 38.

Wallace, Vesna. 2001. The Inner Kālacakra: A Buddhist Tantric View of the Individual. New York: Oxford University Press.

Wallace, Vesna. 2004. The Kālacakratantra: The Chapter on the Individual together with the Vimalaprabhā. New York: Columbia University Press.

(C) 2020 by the author. Licensee MDPI, Basel, Switzerland. This article is an open access article distributed under the terms and conditions of the Creative Commons Attribution (CC BY) license (http://creativecommons.org/licenses/by/4.0/). 